\title{
The Influence of Role Conflict and Role Ambiguity on The Employee's Performance Through Commitment and Self- Efficacy (Study on the Nurses at Public Health Service Center of Kabupaten Kediri, East Java)
}

\author{
${ }^{1}$ DjonyHarijanto, ${ }^{2}$ Prof. Umar Nimran, ${ }^{3}$ Prof. AchmadSudiro, ${ }^{4}$ Dr. \\ MintartiRahayu \\ ${ }^{I}$ (Candidate Doctor of the University of Brawijaya), \\ ${ }^{2} M A$ (Professor Economic of the University of Brawijaya), \\ ${ }^{3}$ (Professor Economic of the Universiy of Brawijaya), \\ ${ }^{4}$ (Doctor of Management of the University ocBrawijaya)
}

\begin{abstract}
The objective of this study is to examine the effect of role conflict and role ambiguity on the organizational commitment, self-efficacy, and employee's performance of nurses at public health service centers (Puskesmas/PusatKesehatanMasyarakat). The data were obtained from 145 nurses as government officers from 35 public health service centers at KabupatenKediri, East Java. The gathered data were then analyzed by using Partial Least Square method; the research result demonstrates that, among the overall proposed hypotheses, role conflict does not influence organizational commitment and nurse's performance so that there is no mediating function of organizational commitment on the relationship between role conflict and performance. The limitation of this research is described on the latest part of this article.
\end{abstract}

Keywords: Role Conflict, Role Ambiguity, Organizational Commitment, Self-Efficacy, Performance, Nurse.

\section{Introduction}

The basic health service center in Indonesia, well-known as PUSKESMAS (PusatKesehatanMasyarakat/ Public Health Service Center), had been built on the almost of the region in Indonesia. Recently, the number of puskesmas in Indonesia is 7,550 units. Even quantitatively the number of puskesmas is already adequate and equally distributed through all over region in Indonesia, qualitatively it is still far below the expected service. It is because of the weak organization and management of the puskesmas, as well as lack of available supporting human resources.

In Nugroho's research (2004), discussing nurse performance at some Puskesmas of KabupatenKudus, demonstrated that age, income, promotion chance, and leadership took a role on the performance of the nurses. In that research, it was found that 40 percent of the respondent (nurse) showed underperformance rate.

Based on the research about productive performance of the puskesmas human resources in Indonesia, it was found that the staff's productive performance was $53.2 \%$; while the rest of it $(46.8 \%)$ was utilized to performance non-productive task. From $53.2 \%$ of the productive performance, only $13.3 \%$ of it was spent for health service activity; meanwhile, the rest $39.9 \%$ of the productive performance was dedicated to health service support activity (Ilyas, 2001). This fact affected the staff's performance himself as well as the performance of the health service institution. In Indonesia, professional nurse only reached $2 \%$ as compared to the whole number of the existing nurses. The number was much lower as compared to the Philippine which had reached $40 \%$ professional nurse who came from bachelor and graduate education backgrounds (Ilyas, 2001).

More specifically, it was said the high role conflict and role ambiguity would reduce job satisfaction as the leader was failed to conduct the norm and ethical code of profession in the organization's activities (Coverman, 1989; Ruyteret.al. 2001; Koustelioset.al., 2004; Tand and Chang, 2010). Role conflict occurred because of the activity process contradicted to the norm and value system applied in an organization (Coverman, 19891 Ruyteret.al., 2001). Role conflict and role ambiguity are important to be investigated deeper since it affect employee performance.

Role stress topic has gained huge attention on several organizational researches, mainly about role conflict and role ambiguity. The concept about role reflects someone's position in a social system related to his right and obligation, as well as authority and responsibility embedded on it.

Goldman and Milman (1969) stated that role conflict is a situation where someone's role expectations come together, both from the individual and from the environment, but those are contradictory. Role conflict can be reduced if a professional does not involve in the administrative or bureaucratic control, since it can limit the activities that are directed to control him himself (Abernethy and Stoelwinder, 1995). 
Based on Luthan (1997), an individual will experience role conflict if he/she gets two or more pressures in one time then he tries to obey one of the pressure. Role conflict will occur of an employee or a professional feel a hardship to adjust the two roles that he is facing. One role, as the organization's member, he must be responsible for the organizational bureaucracy; while the other role, as a professional, he must be responsible for his profession or his job.

Role ambiguity is "no provided feedback information of the evaluation result from the supervisor about someone's performance result related to his chance to get better career, span of responsibility, and the expectations of the role taker" (Katz and Kahn, 1978).

Conflict and ambiguity (pressures on role) historically was perceived to be unpleasant thing for the old actor who had quite strong negative consistent relationship with commitment, involvement, and satisfaction.

High role conflict and role ambiguity will decline job satisfaction if the leader is failed to conduct the norm and ethical conduct of the profession in the organization's activity (Coverman, 1989; Ruyteret al., 2001; Koustelioset al., 2004; Tang and Chang, 2010).

Based on his research, Onyemah (2008) revealed that role conflict and role ambiguity are able to affect performance. Yet, implicitly, Onyemah and other researchers have not achieved a consensus about the dominant factor that is involved on the job stress effect among individual and organizational behaviors.

Research related to role conflict and role ambiguity such as Fisher and Gitelson (1983), as well as Jackson and Schuler (1985), where they investigated the factors that became the antecedent of the role stress, role stress and job outcomes. Role conflict and role ambiguity had been found to have a relationship with the dysfunctional job outcome and attitude related to the job (Jackson and Schuler, 1985).

\section{Research Model and Research Hypotheses Development}

Jackson and Schuler(1985)suggested further research to develop the existing concept of role by considering the role conflict and role ambiguity related to tasks and recognition or rewards.

Most researches about role conflict and role ambiguity frequently correlated these two concepts with job satisfaction (Johnson and Stinson, 1975; Keller, 1975) even for the recent research by Cervoni (2007). Yet, Fisher and Gitelson (1983) had tried to broaden the understanding on the relationship between role conflict and role ambiguity with other constructs.

Yousef(2000) conducted his research by observing that role conflict and role ambiguity simultaneously did neither affect job satisfaction nor employee's reaction to make organizational change.

Stajkovicand Luthans (1998) previously had examined the relationship between self-efficacy and job performance. In overall, self-efficacy was found to bring positive and strong influence on the job-related performance.

The finding that there is a weak and negative relationship between role ambiguity and self-efficacy is supported by other organizational researches. Role ambiguity has been perceived as negative factor that affects organizational matters such as job satisfaction, intention to leave, and self-efficacy (Jackson and Schuler, 1985; Kahn et.al., 1964). Weiner's (2005) study about the school social voluntary worker also found contradicting relationship between role ambiguity and self-efficacy; besides, Weiner's (1985) study concluded that role conflict caused lesser- negative effect and on the self-efficacy if it was compared to the role ambiguity.

From the description above, the following part presents the research hypotheses:

H1 the higher the role conflict perceived by the nurse, the lower the organizational commitment among the nurse is.

H2 The higher the role conflict perceived by the nurse, the lower the self-efficacy sensed by the nurse.

H3 The higher the role ambiguity sensed by the nurse, the nurse's organizational commitment will lessen H4 The higher the role ambiguity perceived by the nurse, the lower self-efficacy will be perceived by the nurse

The worst of the job performance can be instigated by the lack of ability and knowledge that are required to conduct a job, lack of personal factor, or the condition of the organizational environment. McNeese-Smith (1996) demonstrated in the research finding that organizational commitment had positive and significant influence on the employee performance.

Wood and Bandura(1989)emphasized the importance of self-efficacy in the organizational literature for three aspects: the development of the cognitive behavior, the society competence through modeling mastery, the development of self-reliance related to their ability so that the people would utilize their capacity effectively, and the improvement of people motivation through objective section. Wood and Bandura stated that strong selfefficacy was needed to make an individual keep task-oriented in facing organizational difficulties.

H5 The higher the organizational commitment perceived by the employee, the higher the job performance carried out by the nurse. 
H6 The higher the self efficacy perceived by the employee, the higher the job performance level presented by the nurse.

Prior research found that role conflict brought negative influence on the employee behavior such as the overall performance decline (Agustina, 2009; Viator, 2001). Former research, which used auditor as its sample, found that auditors who experienced role overload would affect their job outcome (Abraham, 1997; Almer and Kaplan, 2002; Fogarty, 2000 in Agustina, 2009). Previous research found that the role overload was proved to have relationship with job satisfaction and performance (Fogarty, 2000; in Agustina, 2009).

In sum, self-efficacy predicted and overcame performance behavior (Bandura, 1986); furthermore, prior research by Weiner (2005) about school social voluntary worker also found a contrary relationship between role conflict and role ambiguity on the self-efficacy.

This research is conducted as an effort to observe the influence of role conflict and role behavior on the employee performance through an intervening variable called as commitment and self-efficacy. Former research also proved that role conflict and role ambiguity also affected the improvement of organizational commitment which next influenced the employee performance. The stronger organizational commitment would result on the better performance of the related employee.

H7a Organizational commitment mediates the influence of role conflict on employee performance.

H7b Organizational commitment mediates the influence of role ambiguity on employee performance

H8a Self-efficacy mediates the influence of role conflict on employee performance

H8b Self-efficacy mediates the influence of role ambiguity on employee performance

Figure 1. Conceptual Framework

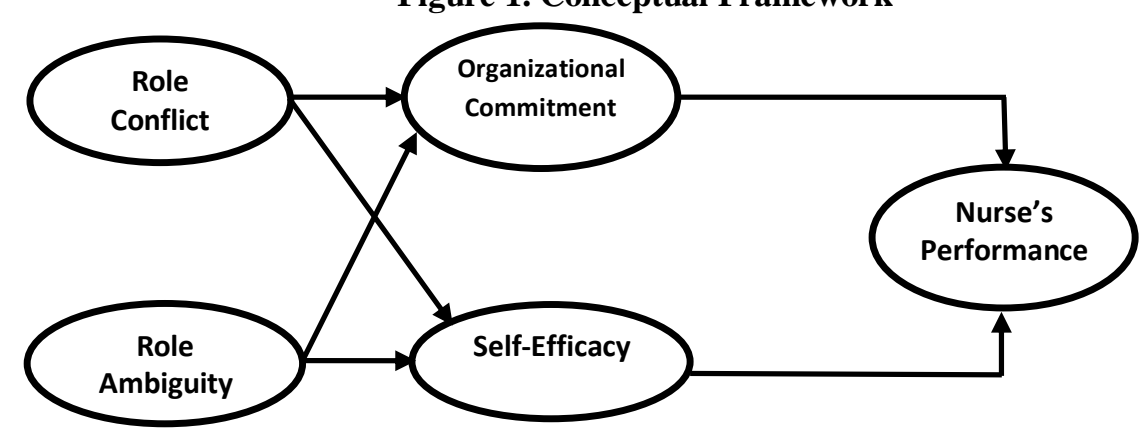

\section{Methodology}

\section{Sample and Procedure}

The researched objects are nurses of Puskesmas in KabupatenKediri, East Java. The research objective is to analyze the perception of those nurses on the role conflict and role ambiguity related to the performance presented by the nurses of Public Medical Service Centers (Puskesmas) in KabupatenKediri, East Java. The research population is all of the nurses in Public Medical Service Centers (Puskesmas)KabupatenKediri, East Java. The preliminary data that had been identified mention that there were 186 nurses as the target of research population census. Nonetheless, since there were some constraints (such as a long period of national leave, nurse training program, some nurses who went out of town for their task in a long period of time, and other unknown reasons), the sample number that was able to be taken from the nurses who worked at the Public Medical Service Centers (Puskesmas) in KabupatenKediri was 145 nurses.

The primary data collection method utilized in this research is by distributing research questionnaires. In this research, the measurement of the respondents' perception was done by a self-rating process where the measurement was conducted unilaterally by the nurses themselves without involving other research subject (for instance: the superintendent of the Public Medical Service Centers (Puskesmas) in Kabupaten Kediri).

\section{Measurement} (five).

In this research, all of the variables are measured using five points of Likert's scale, from 1 (one) to 5

Role conflict is the unmatched condition between the need and the expectation on a role that is ruled by a nurse. It is measured by adopting 10 measurement items from Rizzo, House, and Lirtzman (1970). The result of the reliability construct for role conflict is $\alpha=0.632$.

Role ambiguity in the job occurs because of the lack of expectation, requirement, method, and role information in a situational experience. It is measured by adopting 8 measurement items form Rizzo, House, and Lirtzman (1970). The result of construct reliability for role ambiguity is $\alpha=0.806$. 
Organizational commitment is the willingness to stay in the organization, actively involved in the organization, and feeling as the part of the organization. This is measured by using 15 items of measurement from Allen and Meyer (1991). In addition, the construct reliability result for organizational commitment is $\alpha=$ 0.912 .

Self-efficacy is the individual's level of trust on his competence/capacity to successfully conduct each stage of treatment, reveal particular behavior, and perform particular task, as well as achieve the expected outcome. It is measured by adopting 11 measurement items from Bandura (1986). The construct reliability result for self-efficacy shows $\alpha=0.900$.

Nurse performance is the recognition of nurses in charge as they perform their task as nurses including the quality of job process that can be observed from the task and function as nurses in Public Medical Service Centers (Puskesmas). It adopts 34 measurement items from Mangkunegara (2006) to calculate the nurse performance. The construct reliability for nurse performance displays $\alpha=0.895$.

\section{Analysis and Result}

This research utilized Partial Least Square (PLS) analysis technique which has an advantage as a powerful analysis tool since it does not assume the data with particular measurement scale, particular amount, and can be applied to confirm a theory (Hair et.al., 2010).

From the total number of the respondents, who became the research sample, 30 people among them or $20.69 \%$ of the total respondents were 26 - 35 years old; 40 people or $27.59 \%$ among them were $36-45$ years old; 75 people or $51.72 \%$ among them were 46 - 55 years old. There were 51 males $(35.17 \%)$ and 94 females $(64.83 \%)$ of nurses at Puskesmas in KabupatenKediri, East Java as the respondents of this research. The 130 nurses graduated from diploma program of nursing department (Diploma 3); while, 15 nurses hold bachelor degree in nursing.

Path Coefficient Test Result

\begin{tabular}{|l|c|c|c|}
\hline \multicolumn{1}{|c|}{ Inter-Variables Relationship } & $\begin{array}{c}\text { Original } \\
\text { Sample } \\
\text { Estimate }\end{array}$ & t-statistic & p-value \\
\hline Role Conflict $\rightarrow$ Organizational Commitment & -0.26 & 1.45 & 0.08 \\
\hline Role Ambiguity $\rightarrow$ Organizational Commitment & -0.27 & 1.89 & 0.03 \\
\hline Role Conflict $\rightarrow$ Self-Efficacy & -0.36 & 2.42 & 0.01 \\
\hline Role Ambiguity $\rightarrow$ Self-Efficacy & -0.32 & 2.24 & 0.01 \\
\hline $\begin{array}{l}\text { Organizational Commitment } \rightarrow \text { Nurse } \\
\text { Performance }\end{array}$ & 0.26 & 1.69 & 0.05 \\
\hline Self-Efficacy $\rightarrow$ Nurse Performance & 0.45 & 3.75 & 0.00 \\
\hline
\end{tabular}

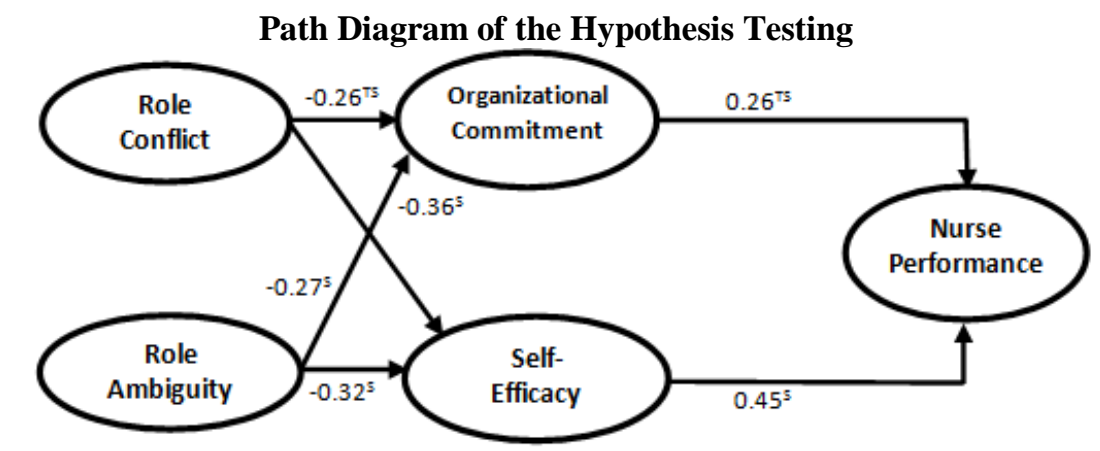

\section{Hypothesis Testing}

The path coefficient between role conflict and organizational commitment demonstrates the score of 0.262 , with 1.45 as its t-statistic value and 0.08 as its p-value; those values respectively are lower that the critical value of 1.76 and higher than the error standard of 0.05 . Thus, Hypothesis 1 is rejected. It proves that there is no significant relationship between role conflict and organizational commitment as the Hypothesis 1 is not accepted.

The path coefficient between role conflict and self-efficacy shows the score of -0.36 . Its t-statistic value is 2.42 ; and, the p-value is 0.01 . Those numbers respectively is higher than its critical value of 1.76 and lower than the error standard of 0.05; therefore, Hypothesis 2 is accepted. It means that there is negative significant relationship between role conflict and self-efficacy. 
Based on the path coefficient value of role ambiguity to organizational commitment, it shows the score of -0.27 , with t-statistic score of 1.89 . This score is below the critical value of 1.76 and its p-value of 0.03 is lesser than the error standard of 0.05. Therefore, it can be stated that Hypothesis 3 is accepted. It proves that there is a contrary (negative) but significant relationship between role ambiguity and organizational commitment.

As displayed on the table and figure above, it was mentioned that the path coefficient value, $t$-statistic, and $p$-value for each variable is $-0.32,2.24$, and 0.01 . The t-statistics is higher than its critical value of 1.76; furthermore, the p-value is lower than the error standard of 0.05. Thus, it implies that Hypothesis 4 is accepted. It demonstrates that there is a significant negative relationship between role ambiguity and self-efficacy.

The score of the path coefficient between organizational commitment and nurse performance is 0.26 , with t-statistic value of 1.69. This score is lesser than its critical value of 1.76; meanwhile, the p-value is equal to the error standard of 0.05 . Therefore, Hypothesis 5 is rejected proofing that there is no significant relationship between organizational commitment and nurse performance.

The path coefficient of the self-efficacy to nurse performance shows 0.45 as its score with t-statistic and p-value are respectively 3.75 and 0.00 . Those scores are higher than its critical value of 1.76; yet, it is lesser than its error standard of 0.05 . Hence, Hypothesis 6 is accepted which implies that there is significant relationship between self-efficacy and nurse performance.

The relationship between role conflict and organizational commitment is proven to be not significant as showed by the t-statistic score which is lesser than its critical value of 1.76. In addition, the relationship between organizational commitment and employee performance is also found to be insignificant. Thus, based on those two relationships, organizational commitment does not have a role as the mediator or mediating variable between role conflict and nurse performance variables.

Role ambiguity has significant influence on organizational commitment as proven by its t-statistic value of 1.89 which is higher than its critical value of 1.76 . The relationship between organizational commitment and nurse performance is proven insignificant since the t-statistic is lower than its critical value, respectively 1.69 and 1.76; therefore, based on the two inter-variables relationships, organizational commitment does not have a role as mediator or mediating variable between role ambiguity and nurse performance. It is because one of the relationships between organizational commitment and nurse performance is not significant.

Role conflict's influence on self-efficacy is proven to be significant as its t-statistic of 2.42 is higher than its critical value of 1.76; further, the relationship between self-efficacy and nurse performance shows tstatistic score of 3.75. Therefore, in the two inter-variables relationships, self-efficacy plays its role as mediator or mediating variable between role conflict and nurse performance.

The relationship between role ambiguity and self-efficacy is verified to be significant as showed by its t-statistic score of 2.24 which is higher than its critical value of 1.76; also, the relationship between self-efficacy and nurse performance gets 3.75 for its score of t-statistic. Thus, the two inter-variables relationships, selfefficacy takes its role as mediator or mediating variable between role ambiguity and nurse performance.

\section{Discussion}

This research discusses the influence of role conflict and role ambiguity on nurse performance based on the organizational commitment and self-efficacy factors among nurses at Puskesmas in KabupatenKediri. In overall, it is found that role conflict does not affect nurse performance; nevertheless, role ambiguity influences nurse performance at Puskesmas in KabupatenKediri. Role ambiguity indirectly affects nurse performance through self-efficacy. Role conflict does not have any relationship with nurse performance; but, it has direct relationship with self-efficacy.

Role conflict brings insignificant relationship with organizational commitment. In other words, the higher the role conflict is, it does not decline the organizational commitment. It can be described by a fact which mentions that nurses have achieved safe zone so that they do not take the role conflict that occurs into account and still keep their commitment to the organization where they work.

Role conflict has significant relationship with self-efficacy; as a consequence, the higher the occurring role conflict, it will decrease the nurse's self-efficacy. This finding is different from the Weiner's study (2005) which demonstrated that the relationship between role conflict had less-influence on self-efficacy. It can be explained by the fact which shows that the occurring role conflict tends to be described by the personal conflict among nurses; meanwhile, self-efficacy is a condition when a nurse knows his/her potential so that it will enhance the chance to correlate the role conflict and self-efficacy. Based on the indicator's weighting value, role conflict tends to be reflected by the inter-senders conflict, while self-efficacy tends to be described by the generalization.

Role ambiguity has significant relationship with organizational commitment of a nurse. This relationship can be described by some facts and information obtained from the nurses. Even role ambiguity is a common thing that occurs; nurses who are experiencing job exhaustion/fatigue sometimes feel that role 
ambiguity affects their organizational commitment. This research is similar with the result of Jackson and Schuler research (1985) which mentioned that role ambiguity had been perceived to be a negative influence that affected organizational factors.

Role ambiguity and self-efficacy have significant relationship. Role ambiguity condition among nurses is generally reflected by the assignment and time allocation as measured from the indicators' weighting score. The result of this result shows that the higher the role ambiguity perceived by the nurse, it will diminish the nurse's self-efficacy. It is similar with the study conducted by Weiner (2005) about social voluntary worker which completely reports that role ambiguity has different correlation to self-efficacy. Role ambiguity has negative correlation with all of the self-efficacy's sub-scales among social voluntary workers in the eight schools that were studied by Weiner.

Organizational commitment does not affect nurse performance. It describes that the higher organizational commitment a nurse has, it does not elevate the performance he/she carries out at Public Medical Service Centers(Puskesmas) in KabupatenKediri. The insignificant relationship between organizational commitment and nurse performance can be explained by the fact which mentions that the performance as a nurse at Public Medical Service Centers(Puskesmas) in KabupatenKediri is evaluated not only based on the daily practice in treating the patients but also based on the length of work that he/she has. The performance measurement of the nurses at Public Medical Service Centers(Puskesmas) in KabupatenKediri is calculated based on the applicable Standard Operating Procedure in general; therefore, the nurse performance is structured even there occurs role ambiguity which is perceived by the nurse just as previously discussed in the part of role ambiguity variable.

Self-efficacy influences nurse performance. The significant relationship between self-efficacy and nurse performance can be investigated from the nurse's reaction on the nurse performance. It is in line with the statement of Bandura and Wood (1989) who found that as individual perceived low personal control, he would demonstrate low self-effectiveness which then decline their performance objective (based on the quantity). Those who perceive high control are reported to have more self-efficacy that set higher objective to be arranged.

Organizational commitment does not mediate the relationship between role conflict and nurse performance. It is confirmed by the insignificant relationship between role conflict and organizational commitment as well as between organizational commitment and nurse performance (based on the t-statistic score). This condition can be scrutinized by the fact from the research location which mentions that nurses have unintentionally ignored the role conflict that they experience since the main objective of them is to be government officers. If those nurses have achieved the safe zone, then they do not any longer worry with any role conflict that occurs. Further, a less-complicated performance measurement as compared to the practice opens a chance for a role conflict happening among nurses takes no effect on their organizational commitment as well as their performance.

Self-efficacy mediates the relationship between role conflict and role ambiguity toward nurse performance. This is confirmed by the significant relationship between role conflict and role ambiguity toward self-efficacy as well as between self-efficacy on nurse performance. This evidence is displayed on the previous table and figure.

\section{Limitation}

1. This research only observed the condition of job exhaustion/fatigue including inter-sender conflict without holistically considering other indicators that affect role conflict such as intra-sender conflict and personal rule's conflict.

2. This research only took sample from general nurse at Public Medical Service Centers (Puskesmas) in Kabupaten Kediri, without examining all of the nurses in the Public Medical Service Centers (Puskesmas).

3. This research was conducted in one-shoot method; it was not done regularly. It was established only for research purpose; therefore, it is impossible to reveal the pattern of the role conflict development.

4. This research utilized self-rating concept that opened a chance to have an individual measurement which was only based on the nurses' perception without involving measurement from the nurses' superintendent. It may cause bias on the gathered information.

\section{Recommendation}

For further research, it is possible to examine all of the nurses who work at the all of Public Medical Service Centers (Puskesmas), at hospitals, and at health department of local government who have not fully dedicated their nursing profession yet. By involving all nurses, it may obtain information and data that are not revealed in this research since this research only focuses on the general nurses. It is expected that the superintendent pays attention on the condition of his/her subordinates (nurses) and is able to make particular assessment to evaluate and improve the quality of the existing human resources. 
The testing and development of the role conflict's indicators based on the nurses' perception, it shows that only one indicator which is proven to be significant that is inter-sender conflict; thus, this indicator is appropriate to be utilized as a measurement tool to reveal the level of the role conflict among nurses in the Public Medical Service Centers (Puskesmas) in KabupatenKediri. This result indicates that the nurses in 35 Public Medical Service Centers (Puskesmas) as the research targets, in general, have similar characteristic with the related Public Medical Service Centers (Puskesmas). The role conflict indirectly supports nurse performance through self-efficacy. To measure the level of the role conflict based on the nurse condition, it can be revealed based on the nurse's perception. The research's contribution in the human resource and workforce realms is the measurement based on the nurse's perception on the role conflict in the organization; suppose, it uses the indicators of role conflict from nurse's perception, called as inter-sender conflict, that has been proven valid and reliable to reflect the role conflict condition in-depth.

The role conflict in human resource and workforce management in an organization has several relatedfactors that are internal and external factors. The internal factors are the performance condition of nurse, organizational condition, and managerial system used by the supervisor or superintendent in the organization. The external factors are other's evaluation on the nurse performance and the recognition/reward of the organization on the environment based on the surrounding society's assessment. These two factors are the important things that is beneficial to reveal the condition of the role conflict in an organization.

Nurse perception in assessing the level of the role conflict in an organization is not only based on the personal conflict from the received work load, but also on the self-efficacy as well as self commitment that they have during working in the organization. At this case, self-efficacy of each nurse is equal to generalization that he/she has as well as the commitment that he/she possesses which are adjusted to nurse attitude in his/her performance. Therefore, the indicators of self-efficacy and self-commitment are good to be used for measuring the level of the role conflict in an organization.

\section{References}

[1] Abernethy, M.A.; Stoelwinder, J.U. 1995.The Role of Professional Control in the Management of complex organizations Accounting, Organization and Society ; 20, 1 -77.

[2] Agustina, Lidya. 2009. PengaruhKonflikPeran, KetidakjelasanPeran, danKelebihanPeranterhadapKepuasanKerjadanKinerja Auditor (Penelitianpada Kantor AkuntanPublik yang BermitraDengan Kantor AkuntanPublikBig Four di Wilayah DKI Jakarta). JurnalAkuntansi Vol.1 No.1 Mei 2009: 40-69.

[3] Allen, Natalie J., John P. Meyer. 1990. The Measurement and Antecedents of Affective, Continuance and Normative Commitment to the Organization. The British Psychological Society :Journal of Occupational Psychology Vol 63, No 1-18.

[4] Allen, Natalie J., John P. Meyer. 1991. A Three Component Conceptualization of Organizational Commitment.Human Resource Management Review, Vol 1 No 1 pp 61 - 89.

[5] Banduras, Albert . 1977. Self-efficacy: Toward a Unifying Theory of Behavioral Change. Psychological Review 1977, Vol. 84, No. 2, 191-215.

[6] Bandura, Albert. 1986. Social Foundations of Thought and Action: A Social Cognitive Theory. Englewood Cliffs, NJ: Prentice-Hall.

[7] Bandura, Albert; Edwin A. Locke. 2003. Negative Self-Efficacy and Goal Effects Revisited. Journal of Applied Psychology 2003, Vol. 88, No. 1, 87-99.

[8] Bandura, Albert. 1989. Social cognitive theory.In R. Vasta (Ed.), Annals of child development.Vol. 6.Six theories of child development (pp. 1-60). Greenwich, CT: JAI Press.

[9] Bandura, Albert; Nancy E. Adams. 1977. Analysis of Self-Efficacy Theory of Behavioral Change. Cognitive Therapy and Research, VoL 1, No. 4, 1977, pp. 287-310.

[10] Cervoni, Annemarie. 2007. Role Conflict, Role Ambiguity, and ASCA Functions as Predictors of School Counselor Job Satisfaction. ProQuest Information and Learning Company : Dissertation Faculty of the Graduate School of the State University of New York at Buffalo.

[11] Coverman, Shelley. 1989. Role Overload, Role Conflict, and Stress : Addressing Consequences of Multiple Role Demands. Social Forces, Vol. 67, No. 4 (Jun., 1989), pp. 965-982.

[12] Fisher, Cynthia D. Dan Richard Gitelson. 1983. A Meta-Analysis of the Correlates of Role Conflict and Ambiguity. Journal of Applied Psvchologv 1983, Vol 68, No 2 320-333.

[13] Goldman, G.D., danMilman, D.S. 1969. Modern women: herpsyche and sexuality. Springfield, Illinois: Charles C. Thomas Publisher.

[14] Hair, J.F., Black, W.C., Babin, B.J., Anderson, R.E. 2010.Multivariate Data Analysis. $7^{\text {th }}$ Edition. Pearson Education Inc. New Jersey.

[15] Ilyas.Y, 2001.KinerjaTeoriPenilaian \&Penelitian.PusatKajianEkonomiKesehatan FKM UI,Depok.

[16] Jackson, Susan. E., Randall S Schuler. 1985. A meta-analysis and conceptual critique of research on role ambiguity and role conflict in work settings. Organizational Behavior andHuman Decision Processes, 36, 16-78.

[17] Johnson, Thomas W. dan John E. Stinson. 1975. Role Ambiguity, Role Conflict, and Satisfaction : Moderating Effects of Individual Differences. Journal of Applied Psychology 1975, Vol. 60, No. 3, 329-333.

[18] Kahn, R., Wolfe, D., Quinn, R., Snoek, J., danRosenthal, R. 1964. Organizationalstress: Studies in role conflict and ambiguity. New York: Wiley.

[19] Katz, Daniel; Kahn, Robert L. 1978.The social psychology of organizations 2nd edition. New York : Wiley.

[20] Keller, Robert T.. 1975. Role Conflict and Ambiguity : Correlates With Job Satisfaction And Values. Personnel Psychology Vol 28, $57-64$.

[21] Koustelios, Athanasios, Nicholas Theodorakis, DimitrisGoulimaris. 2004. Role ambiguity, role conflict and job satisfaction among physical education teachers in Greece. The International Journal of Educational Management Volume $18 \cdot$ Number $2 \cdot 2004 \cdot$ pp. $87-$ 92 Emerald Group Publishing Limited.

[22] Luthans, Fred. 1997. Organizational Behavior. McGraw-Hill Higher Education.

[23] Mangkunegara.AP, 2006.EvaluasiKinerjaSumberDayaManusia, PT. RefikaAditama, Bandung. 
[24] McNesse-Smith, Donna. 1996. Increasing Employee Poductivity, JobSatisfaction, and Organizational Commitment. Hospital and Health Services Administration, 41:2.

[25] Nugroho, M Kris.2004. AnalisisFaktor-faktor yang BerhubunganDenganKinerjaPerawatPegawai Daerah di PuskesmasKabupaten Kudus. UniversitasDiponegoro Semarang - Tesis.

[26] Onyemah, Vincent. 2008. Role Ambiguity, Role Conflict, and Performance: Empirical Evidence of an Inverted-U Relationship. Journal of Personal Selling \& Sales Management, Vol. 28, No. 3, 299-313.

[27] Rizzo, J.R., House, R.J., Lirtzman, S. 1970. Role conflict and ambiguity in complex organizations.Administrative Science Quarterly, Vol. 15 pp.150-63.

[28] Ruyter, Ko De, Martin Wetzels, Richard Feinberg.2001. Role Stress in Call Centers : Its Effects On Employee Performance and Satisfaction. John Wiley And Sons : Journal of Interactive Marketing Vol 15 No 2 Spring 2001.

[29] Stajkovic, Alexander D., Fred Luthans. 1998. Self-Efficacy and Work - Related Peformance : A Meta - Analysis. Psychological Bulletin 1998, Vol. 124, No.2, $240-26$.

[30] Tang, Yung-Tai dan Chen-Hua Chang. 2010. Impact of role ambiguity and role conflict on employee creativity. African Journal of Business Management Vol. 4(6), pp. 869-881.

[31] Viator, Ralph E. 2001.The Association of Formal and Informal Public Accounting Mentoring With Role Stress and Related Job Outcomes.Accounting, Organizations and Society. 26: 73-93.

[32] Weiner, Susan. 2005. Role conflict, role ambiguity, and self-efficacy among socialworkers. Dissertation Abstracts International, 66 (11). (UMI No.3195886).

[33] Wood, R., dan Bandura, A. (1989).Social cognitive theory of organizational management. Academy of Management Review, 14(3), 361-384.

[34] Yousef, Darwish A. 2000. Organizational commitment: a mediator of the relationships of leadership behavior with job satisfaction and performance in a non-western country. Journal of Managerial Psychology, Vol. 15 Iss: 1, pp.6 - 24. 